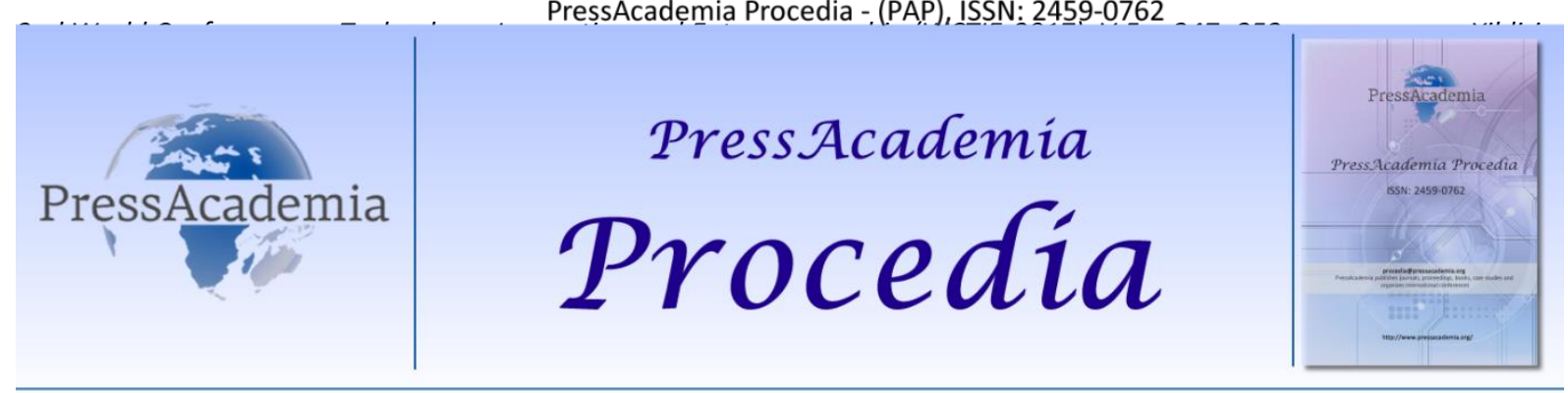

2nd World Conference on Technology, Innovation and Entrepreneurship

May 12-14, 2017, Istanbul, Turkey. Edited by Sefer Şener

\title{
OBSERVATIONS AND RECOMMENDATIONS FOR THE WOMEN ENTERPRENEURSHIP IN INFORMATION TECHNOLOGY
}

DOI: 10.17261/Pressacademia.2017.596

PAP-WCTIE-V.5-2017(34)-p.247-252

Ayca Tuzmen Yildirim ${ }^{1}$

${ }^{1}$ Okan University, ayca.tuzmen@okan.edu.tr

\begin{abstract}
Women entrepreneurship is a process that is being encouraged, publicized and directed by governmental and non-governmental organizations. There are many forces that allows emergence of the women entrepreneurship in IT. In this paper, I opt to discuss and comment on the journey of the women workforce in IT from corporate organizations to the workforce in women entrepreneurship. This paper introduces observations of the changes in women workforce in corporate USA and Turkey, and introduces the offerings and challenges observed in the designing, launching and running of a new IT business at Incubation centers and universities in Turkey. This paper also offers recommendations for governmental and non-governmental policies of small businesses and recommendations for the strategies of the incubation centers that would help women entrepreneurship.
\end{abstract}

Keywords: Women entrepreneurship, information technology, incubation center, academia

\section{INTRODUCTION}

A growing literature in entrepreneurship focus on the theory and definition of entrepreneurship, innovation (Cantillon, 1964); on the forces and motivations for entrepreneurship (Knight, 2005; Sorensen and Nanda, 2013), behaviors of entrepreneurs (Hanssan, 2012), experiences and strategies of entrepreneurs (Navale, 2013). Published research studies of the female entrepreneur have ranged from psychological and demographic studies (Sexton and Bowman-Upton, 1990; Ahl, 2003) to perceived start-up obstacles (Hisrich and Brush, 1984). While these research help us fully understand the motivation of women entrepreneurship, mechanics of entrepreneurship process; we still need to reflect upon the understanding, mechanism and strategies for women entrepreneurship in Information Technology.

This paper makes an inquiry into women entrepreneurship in Information Technology in Turkey. It focuses on the question "What are the motivations and strategies for women entrepreneurship in Information Technology?". Are women in Information Technology being stimulated by a "She can do it, why can't I?" attitude or not? The aim of this paper is to better understand the mechanics that drive the entrepreneurship process in Information Technology undertaken by women entrepreneurs.

This study is important to show the variation of research on women entrepreneurship and make an inquiry into their findings. This paper questions the motivations and demotivatios for women entrepreneurs in IT and discusses the validity of the strategies for improving the mechanics of the entrepreneurship process.

The paper is organized into three sections. In section 2, literature on the observations and research on entrepreneurship are introduced. In section 3, the inquiries into the findings of research on women entrepreneurship are made. The final section concludes the paper with recommendations and suggestions for women entrepreneurs and policy makers in Information Technology in Turkey. 


\section{INQUIRY INTO WOMEN ENTERPRENEURSHIP}

Entrepreneurship has been defined as the willingness to take risk in the new name of an idea, spending time as well as capital on an uncertain venture to make profit (Knight, 2005; Drucker, 2006; Brush et al, 2003). Empirical studies have shown that people are drawn to entrepreneurship due to many driving forces. Sorensen (2013) suggested that significant influences on the decision to become an entrepreneur are workplace peers and social composition. If one entrepreneur is successful in venture, others are also influenced by the demonstration of the possibility of success. After seeing entrepreneurs like Steve Jobs, Mark Zuckerberg, Trabis Kalancik, Nevzat Aydin, social composition stimulates a "He can do it, why can't I?" attitude.

Even though, social composition and workplace peers are to be major driver for entrepreneurship, women entrepreneurs seem to have less such influences since most of the social composition and workplace peers seems to be coming from success stories of men.

Studies by Burton et al (2002), Wagner (2004), Dobrev and Barnett (2005), Gompers et al (2005), Sorensen and Nanda (2013), Elfenbein et al (2010), Parker (2009) provided evidence of the importance of the workplace in the entrepreneurial process. Workplace is particularly important source of entrepreneurial influence in modern societies; therefore, the workplace becomes the setting for unexpected influences, and for the serendipitous flow of information and ideas that may spark entrepreneurial activity (Nanda and Sorensen, 2010)

Even though workplace is the setting for unexpected influences, and for serendipitous flow of information and ideas that may spark entrepreneurial activity; we see less women entrepreneurs in IT sharing workplaces such as in incubation centers, teknoparks or universities in Turkey and therefore having less opportunity to increase the impact of social composition and workplace peer to the mechanics of entrepreneurship process. This further explains why certain regions show variations in rates of women entrepreneurship.

Entrepreneurs are also driven to entrepreneurship by past experience. As Hansson's study suggests, if one has faced multiple work stoppages or have been unemployed in the past, the probability of becoming an entrepreneur has increased (2012). Past experience as well as present experience in workforce is a significant driver for an increase in entrepreneurship in areas where unemployment rate is high, creation of new job opportunities is low (European Commission, 2012). Work stoppers and unemployment in Information Technology are on the rise among women tech makers in Turkey, therefore one would expect an increase in trend in women entrepreneurship in Information Technology.

Knight believed that entrepreneurs are faced with three types of uncertainty: 1) risk which is measurable statically, 2) ambiguity which is hard to measure statically and 3) true uncertainty which is impossible to estimate or predict statically (2005). Risk is seen as the probability of drawing a red ball from a jar containing 5 red balls and 5 white balls. Ambiguity is seen as the probability of drawing a read ball from a jar containing 5 red balls but an unknown number of white balls. On the other hand, true uncertainty is seen as the probability of drawing a red ball from a jar whose contents are entirely unknown.

Given Knight's classification of uncertainty (2005), entrepreneurships are believed to face true uncertainty when it comes to the creation of novel good or service, for a market that did not previously exists rather than when a venture creates an incremental improvement to an existing product or service. Innovations in IT which requires creation of novel good or service, calls for entrepreneurships in IT which are associated with true uncertainty. Therefore, most of the women entrepreneurs in IT are faced with uncertainty in their venture and therefore the question is needs to be examined is whether this is a factor demotivating women tech makers in Turkey.

Empirical studies have looked into similarities and difference in male and female entrepreneurship (Hansson, 2005). It is been observed that there are more similarities than difference between them. The start-up process has been reported similar for men and women, and women appear to have no specific difficulties or information needs (Alsos \& Ljunggren, 1998; Birley, Moss, \& Saunders, 1987; Dolinsky, 1993; Marlow, 1997; Nelson, 1987). Women seem to be discriminated against by banks in several studies, but the explanations appear to be mainly structural; they own the types of businesses that banks associate with higher risks (Buttner \& Rosen, 1988; Buttner \& Rosen, 1992).

Literature consists of research which hypothesized the family to be of special significance for women entrepreneurs, either as an obstacle or as a resource (Caputo \& Dolinsky, 1998; Dumas, 1992; Holmquist \& Sundin, 1990; Nelson, 1987, Ufuk and Ozgen, 2001). Balancing family and work is experienced as a problem for many women entrepreneurs, but the studies do not report if men have similar feelings (Stoner, Hartman, \& Arora, 1990).

Empirical studies from Sweden found that the probability of becoming self-employed decreases with age for women, but increases with age for men (Hanssan, 2012). On the other hand, the results of research carried out in European countries, United States of America and Turkey show that women entrepreneurs tend to be older (Ecevit, 2017). This study also 
showed that marriage increases the probability of a person becoming an entrepreneur. There are no research which studies the correlation of age and marriage to women entrepreneurship in Information Technology in Turkey; therefore, it is hard to comment on the influence of age and/or marriage on women entrepreneurship in Information Technology in Turkey.

Literature consists of studies which looked into the performance or underperformance of women entrepreneurs (Zapalaska, 1976; Chaganti \& Parasuraman, 1996; Chell \& Baines, 1998; DuRietz \& Henrekson, 2000). They questioned if women entrepreneurs do at all "possess the characteristics required for effective performance as entrepreneurs". These led to the development of polarized measuring instruments (Buttner \& Rosen, 1988; and Fagenson \& Marcus, 1991) which had a masculine and a feminine scale. The items in the masculine scale were "competitive, active, independent, able to make decisions, does not give up easily, feels very superior, self-confident", and "stands up well under pressure". The feminine scale was comprised of "emotional, understanding, warm, able to devote oneself completely to others, gentle, helpful to others, kind", and "aware of others' feelings". The studies that look for psychological differences between men and women entrepreneurs, however, very few, if any, differences between men and women entrepreneurs are found.

\section{DRIVING FORCES AND STRATEGIES FOR WOMEN ENTREPRENEUSHIP}

Past experience in previous workplaces is the motivator for women entrepreneurship. However, there are few researches documenting whether these experiences are pleasant or unpleasant experiences which are leading women into the venture of creating their new business. There is the hypothesis that most of these experiences are unpleasant therefore women are more inclined towards creating their own business rather than searching for better workplace experience.

There are also few studies that focus on how many of women use their past experience in information technology into the creation of new IT business. Since innovations in IT calls for entrepreneurships which is associated with true uncertainty; one can argue whether women entrepreneurs opt to undertake new business with high uncertainty or one that requires less risk and ambiguity. The practical thinking will suggest that past experience in one area of expertise should be in better use in the creation of a new business in the same area of expertise. However, we still see vast amount of women entrepreneurs coming from information technology but moving on to different areas of business such as merchandising and service type of businesses. The question that comes into concern is "what factors demotivates women going into information technology business even though their past experiences lies in IT?" . Does having family, age, capital, culture, governmental or institutional policies play an important role in this? If so, how can we reshape these influencers so that more women can create new business in Information Technology in Turkey?

Certain regions are more prone to influence innovation in Information Technology. Since Silicon Valley is a great example for such observations, many tech maker aims to start their venture in this regions. All around the worlds and well as in Turkey, similar hubs are planned and are being introduced in order to attract entrepreneurs. As of December 2015, there are 63 teknokent are approved and out of 49 are operational in Turkey. There are 3744 firms in these centers and $39 \%$ of them are in software development; $19 \%$ in IT, $7 \%$ in electronics, $\% 5$ machine manufacturing, and $40 \%$ in medical, chemistry, food, automotive, defense business (TGBD, 2017). However, there is no research showing how many women tech makers are drawn into such hubs in information technology and how many of them are admitted as business owners.

Many strategies have been taken by entrepreneurs in their venture in tackling uncertainty, risk and ambiguity. Since balancing family and work is experienced as a problem for many women entrepreneurs (Stoner, Hartman, \& Arora, 1990) and thus, strategies have been recommended for formulizing the family and new business equation. Caputo and Dolinsky (1998) recommends their government to supply micro-loans for women business starters, since home-based entrepreneurship makes it possible to care for children and run a business at the same time, thereby saving taxpayers money for dependent care. A more Scandinavian approach calls out for public childcare in which case men and women can participate in the labor force and provide childcare on equal terms. The recommendation of this paper would be the combination of both approaches for supporting women tech makers in Turkey.

Institutionalization of support systems for women are common throughout Europe (Wegate, 2017), USA (Women Entrepreneurs Organization, 2017), Canada (Business Women in International Trade, 2017), Turkey (TOBB Istanbul Kadin Girisimciler Kurulu, 2017) and across regions (WeMena, 2017; Women Tech Makers, 2017). Supportive measures include such as:

- $\quad$ promotions of women entrepreneurs

- $\quad$ support networking among female entrepreneurs, potential female entrepreneurs and support organizations

- $\quad$ award women entrepreneurs

- $\quad$ provide focused trainings and workshops

- $\quad$ mentorship by men and women for women entrepreneurs

- dissemination of information on the services provided by other entrepreneurship supporting funds and foundation 
- $\quad$ providing free consultations to business in their starting phase,

- $\quad$ scholarships for women entrepreneurs

- $\quad$ providing the starting businesses with a package of the related materials,

- $\quad$ informing businesses of the measure of the support systems to entrepreneurship

- $\quad$ allowing access to capital through micro lending, seed capital, and angel investing

- increasing visibility, scale and reach of existing support programs

\section{RECOMMENDATIONS AND CONCLUSION}

We see leadership positions taken by women in business and universities in Turkey; however one thing we know from observations is that the numbers are insufficient and that women in some areas are waiting for companies to give them the leadership positions they deserve (Compass, 2015). We need more women techmakers in Turkey. It seems clear that most, if not some of the essential components of an effective support infrastructure for women entrepreneurship in Information Technology needs to be found in Turkey. Therefore, this section focuses on the question "What are the major strategies women entrepreneurs can use in order to be successful?"

We would see more women entrepreneurs in Information Technology by promoting their stories and strategies. Advocating women entrepreneurs such as Coco Chanel, Joy Mangano, Martha Steward, Sara Blakely as well those in IT such as Peng Lei, Gina Bianchini, Cher Wang stimulate a "She can do it, why can't I?" attitude. Through organizations such as Girlsintech, WeMena.org, Womentechmakers among Turkish women in IT and allowing unexpected influences, and serendipitous flow of information, ideas and collaboration in IT may spark more women entrepreneurial activity in Turkey.

In order to increase innovation in information technology, workplaces such as incubation centers, teknoparks and universities should bring together more women and foster their collaboration in a single workplace. By having more women peers in a workplace and their social compositions, we can expect the emergence of further innovations by women in Information Technology.

Construction of an ecosystem which holds the ingredients needed to support women techmakers in IT would require support mechanisms for balancing family life and work. Incubation centers, teknoparks and universities which require spending a certain amount of time at a certain location and measuring their success in terms of how many hours they spend in a certain location does not allow fostering of innovation and construction of work and life balance.

Studies show that innovation, creativity and entrepreneurship does not happen miraculously by spending a certain amount of time at a certain location (Rehman and Roomi, 2012; Walker et al, 2008). Entrepreneurship through home-based business ownership is recommended as a potential solution to the inter-role conflict experienced by women attempting to balance dual work and family roles (Walker et al. 2008). Incubation centers, teknoparks and universities which do not impose time-based access but instead support women entrepreneurs in their business venture to develop, test, market and improve customer and partner relationships are needed by women techmakers in Turkey. However, access to an entrepreneurial ecosystem on a need basis should also be provided to women entrepreneurs by allowing them access to incubation center, teknoparks and university research centers.

We need further studies showing which regions are attracting women entrepreneurs in information technology. There is no research in Turkey, showing how many women tech makers are drawn into teknoparks and incubation center in information technology and how many of them are admitted as business owners. We need to understand whether acceptance criteria for entering women entrepreneurs are seen as obstacles in such hubs. Further, we need to study whether offerings in such hubs are geared towards the needs and expectations of the women entrepreneurs. Improvements on acceptance criteria and offerings of the IT regions, which are not able to attract women tech makers and/or not able to support them in their venture, should be defined and introduced.

A commitment to increase the share of government economic development resources that is made available to women entrepreneurship in Information Technology is needed. A recognition that apart from legislator and regulator, governmental organizations should have the three principal role in the facilitation of entrepreneurship and small business development - as advocate, investor and enabler. In order to play the role of the investor, the governmental and nongovernmental agencies will need to increase the scale and scope of the investment pool for women entrepreneurs. The enabler role requires that government help entrepreneurs navigate the regulatory process during the start-up of new business as well as while running it. The advocator role requires that women entrepreneurship in Information Technology is advocated to women in all ages, regions, status and income. Governmental and non-governmental offerings and support to women entrepreneurs should not be limited to only new graduates at certain regions, but should be extended to all women with or without experience, with or without formal training, with or without capital, with or without physical access to a specific region or location. 


\section{REFERENCES}

Ahl, H. J. 2003, "The Scientific Reproduction of Gender Inequality: A Discourse Analysis of Research Articles on Women's Entrepreneurship".

Alsos, G. A. and Ljunggren, E., 1998, "Does the business start-up process differ by gender? A longitudinal study of nascent entrepreneurs", In P. D. Reynolds, W. D. Bygrave, S. Manigart, C. M. Mason, G. D. Meyer, N.M. Carter, \& K. G. Shaver (Eds.), Frontiers of entrepreneurial research, pp. 137-151). Boston, MA: Babson College

Beatty, J. 1998, "The World According to Peter Drucker", pp. 163.

Birley, S., Moss, C., \& Saunders, P., 1987, "Do women entrepreneurs require different training?", American Journal of Small Business, vol. 12 , no. 1 , pp. $27-35$

Brush et al, 2003, "Women Entrepreneurs: Moving Front and Center: An Overview of Research and Theory", Retrieved on March 22, 2017, http://www.unm.edu/ asalazar/Kauffman/Entrep_research/e_women.pdf

Burton, M. D., J. B. Sørensen, C. Beckman. 2002. "Coming from good stock: Career histories and new venture formation", Res. Social. Organ. 19, pp. 229-262

Buttner, E. H. 2001, "Examining female entrepreneurs' management style: an application of a relational frame. Journal of Business Ethics, vol. 29 , no. 3 , pp. 253-269.

Buttner, E. H., \& Rosen, B., 1992, "Rejection in the loan application process: Male and female entrepreneurs' perceptions and subsequent intentions", Journal of Small Business Management, vol. 30, no. 1, pp. 58-65.

Cantillon, R. 1964, "Essoi Sur Lo Noture Du Commerce En Gindral", Augustus M. Kelley: pp. 29.

Caputo, R. K., \& Dolinsky, A., 1998, "Women's choice to pursue self-employment: The role of financial and human capital of household members", Journal of Small Business Management, vol. 36, no. 3, pp. 8-17

Chaganti, R., \& Parasuraman, S., 1996, "A study of the impact of gender on business performance and management patterns in small businesses", Entrepreneurship Theory and Practice, vol. 21, no. 2, pp. 73-75

Chell, E., \& Baines, S., 1998, "Does gender affect business' performance'? A study of micro-businesses in business services in the U.K", Entrepreneurship and Regional Development, vol. 10, no. 2, pp. 117-135

Dobrev, S. D., Barnett, W. P., 2005, "Organizational roles and transitions to entrepreneurship", Acad. Management J, vol. 48, no. 3, pp. 433-449.

Dolinsky, A. L., Caputo, Pasumarty, R. K., \& Quazi, H., 1993, "The effects of education on business ownership: A longitudinal study of women", Entrepreneurship Theory and Practice, vol. 18, no. 1, pp. 43-53.

Druker, P., 2006, “Innovation and Entrepreneurship: Practice and Principle” Routledge Classics.

Dumas, C., 1992, "Integrating the daughter into family business management", Entrepreneurship Theory and Practice, vol. 16, no. 4, pp. 4155.

DuRietz A. \& Henrekson, M., 2000, "Testing the female underperformance hypothesis", Small Business Economics, vol. 14, pp. 1-10

Ecevit, Y. "Research on Women Entrepreneurs", Retrieved March 22, https://assets.garanti.com.tr/assets/pdf/tr/diger/K.G.A_eng_dijital_v_1.pdf

Elfenbein, D. W., B. H. Hamilton, W. B. and Zenger, T. R., 2010, "The small firm effect and the entrepreneurial spawning of scientists and engineers", Management Science. 56 (4) 659-681

European Commission, "Statistical Data on Women Entrepreneurs in Europe-2014", Retrieved March 22, 2017, http://ec.europa.eu/DocsRoom/documents/7481/attachments/1/translations

Evaluation of Women's Enterprise Initiative (n.d.). Retrieved March 22, 2017, https://www.wd-deo.gc.ca/eng/18274.asp

Fagenson, E. A., \& Marcus, E. A.,1991, "Perceptions of the sex-role stereotypic characteristics of entrepreneurs: Women's evaluations", Entrepreneurship Theory and Practice, vol. 15 , no. 4, pp. 33-47

Girls in Tech (n.d.) Retrieved March 22, 2017, from http://girlsintech.org/\#programs

Gompers, P., J. Lerner, D., 2005, "Entrepreneurial spawning: Public corporations and the genesis of new ventures", J. Finance, vol. 60, No. 2, pp. 577-614.

Hanssan, A. 2012, "Tax Policy and Entrepreneurship: Empirical Evidence from Sweden", Small Business Economics.

Hisrich, R. D. and Brush, C., 1984, "The woman entrepreneur: Management skills and business problems", Journal of Small Business Management, vol. 22, no. 1, pp. 30-37 
Holmquist, C., and Sundin, E.,1990, "What's special about highly educated women entrepreneurs", Entrepreneurship and Regional Development, vol. 2, pp. 181-193.

Knight, F. H. 2005, "Risk, Uncertainty and Profit", Cosimo: pp. 22-40.

Marlow, S., 1997, "Self employed women: New opportunities, old challenges", Entrepreneurship and Regional Development, vol. 9, no. 3, pp. 199-210.

National Association of Women Business Owners 2007 Survey of Women Business Owners. http://businesscommunicationnetwork.com/wp-content/plugins/BNet/cache/1312925017917.pdf

Navale, A. B. 2013, "Developing Entrepreneur Skills for Corporate Work", Research Directions, vol 1, no. 4, pp.

Nelson, G. W., 1987, "Information needs of female entrepreneurs", Journal of Small Business Management, vol. 25, no. 1, pp. 38-44.

Parker, S. C. 2009. "Why do small firms produce the entrepreneurs?", J. Socio-Economic. vol. 38, vol. 3, pp. 484-494.

Rehman, S. and Roomi, M. A. 2012, "Gender and Work-life Balance: A Phenomenological Study of Women Entrepreneurs in Pakistan", Journal of Small Business and Enterprise Development, vol. 19, no. 2, pp.209 - 228.

Sexton D. L. and Bowman-Upton, N., 1990 "Female and Male Entrepreneurs: Psychological Characteristics and Their Role in Gender-related Discrimination". Journal of Business Venturing, vol 5, no 1, pp 29-36.

Sorensen, J., Nanda, R. 2013, "Workplace Peers and Entrepreneurship", Management Science, vol 56, no . 7, pp. 1116-1126.

Stoner, C. R., Hartman, R. I., \& Arora, R.,1990, "Work-home role conflict in female owners of small businesses: an exploratory study", Journal of Small Business Management, vol. 29, no. 1, pp. 30-38

TGBD, 2017, “Turkiyede Teknoparklar”, Retrieved March 22, 2017, http://www.tgbd.org.tr/WebContent/WebContent/4707

TOBB Istanbul Kadin Girismciler Kurulu, Retrieved March 22, 2017, http://www.ikgk.org.tr/

Ufuk, H., \& Ozgen, O., 2001, "Interaction between the business and family lives of women entrepreneurs in Turkey" , Journal of Business Ethics, vol. 31, no. 2, pp. 95-106.

Wagner, J. 2004, "Are young and small firms hothouses for nascent entrepreneurs? Evidence from German micro data", Appl. Econom. Quart. vol. 50, no. 4, pp. 379-391.

Walker, W. et al., 2008, "Women and worklife Balance: Is Homebased Business Ownership the Solution?", Equal Opportunities International, vol. 27 , no. 3, pp.258 - 275 .

WeGate, (n.d.). Retrieved March 22, 2017, https://www.wegate.eu/who-we-are

Women Entrepreneurs MENA (n.d) Retrieved March 22, 2017, from http://www.we-mena.org/

Women TechMakers, (n.d.). Retrieved March 22, 2017, https://www.womentechmakers.com

Zapalska, A.M., 1997, "A profile of women entrepreneurs and enterprises in Poland", Journal of Small Business Management, vol. 35 , no. 4, pp. 76-82. 